\title{
Determination of the weighting factors of criteria influencing highway flooding using Multi Criteria Analysis based on an Analytic Hierarchy Process
}

\author{
S. Budhakooncharoen ${ }^{1} \&$ B. Dhabhisara ${ }^{2}$ \\ ${ }^{1}$ Mahanakorn University of Technology, Thailand \\ ${ }^{2}$ Chulalongkorn University, Thailand
}

\begin{abstract}
Flooding is one of the major natural disasters affecting millions of people. Thailand is also frequently faced with this type of disaster. In particular, the 2011 mega flood in Central Thailand, which inundated highways, severely contributed to the failure of national economies and increased the risk to life. Lessons learned from such an extreme event encouraged flood monitoring and warning, two basic elements of sound mitigation. Weighting factors for each cause of highway flooding are considered as essential information for classifying the degree of highway flood hazard and to enable flood monitoring and flood warning in hazardous areas. We have investigated the causes of highway flooding and have found that the three major factors that influence highway flooding are the characteristics of the highway, the hydrology and the land topography. The importance of each cause of highway flooding in the whole country was assessed by weighting these three major factors using a Multi Criteria Analysis (MCA) based on the Analytic Hierarchy Process (AHP). The MCA, based on the AHP, was selected due to its' being a structured technique for organizing and analyzing complex decisions based on mathematics and psychology. According to the results of MCA, the highway, the hydrological and the topographic characteristics of the land were weighted as 35,35 and 30 percent, respectively, regards to influencing or causing highway floods. These weighting factors are estimated values indicating the relative importance or
\end{abstract}


impact of each highway flood cause in a whole as compared to each other. The methodology of weighting factors determination will be clearly presented in this paper. These factors are applicable for set ting the priority for working out how to fix the problems and help reduce flood incidents. In addition, these factors will provide essential information for further study in classifying the degree of flood for highway flood hazard mapping.

Keywords: Analytic Hierarchy Process, flood hazard, flood mitigation, Thailand flood, Multi Criteria Analysis.

\section{Introduction}

Global warming in recent decades and its projected continuation is the major concern of various human sectors. Since the past decades, many urban areas in the world have been experiencing a dramatic increase in natural disasters due to water-related extreme events. The lack of precipitation as well as heavy downpour causes disasters ranging from extreme drought to unprecedented flood. In addition, climate change, environmental degradation, population growth, urbanization and anthropogenic effects cause human society to be more vulnerable to water-related disasters.

Flooding is one of the major natural disasters affecting millions of people, destroying property and resulting in loss of human life. Nowadays, the world is facing an increasing number of floods, not only in inundated areas but also in their frequency. Thailand is also frequently faced with this type of disaster especially the 2011 mega flood in central area of the country, Chao Phraya river basin, which severely attributed to the failure of industry and agriculture.

Even the residents in the Chao Phraya and related basins have learnt to adapt their lifestyle to deal with the recurrent flood cycle by investigating the variation of the rain, water stage and surrounding environments, the 2011 mega flood in Central Thailand is one of the hardest cases. Highway flooding in that year severely contributed to the failure of national economies and increased the risk to life. Lessons learned from such an extreme event encouraged flood monitoring and warning; two basic elements of sound mitigation. This is because highway flooding is a potential risk to life and limb and can potentially damage property. Flood monitoring and warning help mitigate loss of lives and property losses.

Even the flood hazard mapping was successfully accomplished in some areas in Thailand, for example in Nan River Basin (Somchit et al. [1]), Upper Pasak River Basin (World Bank Group [2]), Bangkok and Hadyai areas (Department of Disaster Prevention and Mitigation [3]) and in the flood risk areas (Department of Disaster Prevention and Mitigation [4]), however, highway flooding has never been theoretically classified into various degrees of hazard. Weighting factors for each cause of the highway flooding are essential information for classifying the degree of highway flood hazard (Budhakooncharoen [5]) which is a major step for highway flood hazard mapping and for enabling flood monitoring and warning in hazardous areas. 


\section{Object of study}

The objective of this study is to investigate the causes of highway flood, then, to apply the Multi Criteria Analysis (MCA) based on the Analytic Hierarchy Process (AHP) to determine the weighting factors of importance for each cause of the highway flood for the whole Kingdom of Thailand.

\section{Methodology and theoretical considerations}

\subsection{Methodology}

The degree of flood hazard varies with circumstances across the full range of floods. In this research, the causes of highway flood were investigated by using relevant historical records. They are namely historical highway flood, hydrological time series and basin topographical characteristics. Then the weighting factors for each cause of highway flooding were assessed by using the Multi Criteria Analysis (MCA) based on the Analytic Hierarchy Process (AHP) (Saaty $[6,7]$ ).

\subsection{Theoretical considerations}

Weighting factors are the estimated values indicating the relative importance or impact of each item in a group as compared to the other items in the group. The purpose of assigning the weighting factors is to help us define the level of importance or impact of criteria. This process necessarily assigns numeric values to judgments. These judgments should not be arbitrary or subjective, but should reflect expert views, and should be supported by objective information. To achieve the meaningful results which ones can rely on, the AHP, which was developed by Thomas L. Saaty in 1970, was used in this study. This is because AHP is a structured technique for organizing and analyzing complex decisions based on mathematics and psychology. The AHP application involves the mathematical synthesis of numerous judgments about the decision problem at hand. The procedure can be subdivided into 4 steps, namely problem decomposition, establish priorities, consistency check and final conclusion. The details of each step are as follows:

Step 1 Problem decomposition: The first step in the analytic hierarchy process is to decompose the decision problem into a hierarchy of more easily comprehended sub-problems. The elements of the hierarchy can relate to any aspect of the decision problem either tangible or intangible. It may contain the decision goal, the alternatives for reaching it, the factors influencing or the criteria for evaluating the alternatives.

Step 2 Establish priorities: Once the hierarchy has been constructed, the priorities, the importance or the impacts among the elements of the hierarchy will be established by decision maker(s) or expert(s) by making a series of judgments based on pair-wise comparisons of the elements. The criteria are pairwise compared against the judgment for importance. The comparisons are 
mathematically processed, and the priorities are derived. The AHP converts these evaluations to numerical values that can be processed and compared over the entire range of the problem. The priorities are absolute numbers between a range of number from 'least effect than', to 1 for 'equal', and to the 'absolutely more important than' covering the entire spectrum of the comparison. Table 1 illustrates the sample of the priority matrix of a 3 criterion problem.

Table 1: Sample of the priority matrix of a 3 criterion problem.

\begin{tabular}{|c|c|c|c|}
\hline Criteria & 1 & 2 & 3 \\
\hline 1 & 1 & $1 / x_{21}$ & $1 / x_{31}$ \\
\hline 2 & $\mathrm{x}_{21}$ & 1 & $\mathrm{x}_{23}$ \\
\hline 3 & $\mathrm{x}_{31}$ & $1 / x_{23}$ & 1 \\
\hline
\end{tabular}

Step 3 Consistency check: Check the consistency of the judgments by perform the calculations to find the maximum Eigen values, consistency index CI, consistency ratio $\mathrm{CR}$, and normalized values for each criterion. If the maximum Eigen values, CI, and CR are satisfactory then decision is taken based on the normalized values; else more information has to be supplied to the decision maker(s) or the expert(s), then the procedure is repeated till these values lie in an acceptable range.

The consistency index CI can be computed as follows:

$$
\begin{gathered}
\mathrm{CI}=(\lambda-\mathrm{n}) /(\mathrm{n}-1) \\
\left.\lambda=\sum_{\mathrm{i}=1}^{\mathrm{n}}\left[\left(\sum_{\mathrm{j}=1}^{\mathrm{n}}\right) \mathrm{x}_{\mathrm{ij}}\right) \mathrm{xw}_{\mathrm{i}}\right]
\end{gathered}
$$

where $\mathrm{n}=$ number of criteria for comparison,

$\mathrm{X}_{\mathrm{ij}}=$ relative priorities (pair-wise comparison between criteria $\mathrm{i}$ and $\mathrm{j}$ ),

$\mathrm{w}_{\mathrm{i}}=$ normalized weight of criteria $\mathrm{i}$ (See the detail how to compute this value in the section "Results and discussions").

The consistency ratio $(\mathrm{CR})$ can be computed as $C R=\frac{C I}{R C I}$.

RCI is the random consistency index. It varies according to the number of criteria for comparison (n) as shown in Table 2. Then compare CR with the following acceptable range as follows: 


$$
\begin{aligned}
& \mathrm{CR} \leq 0.10 \text { for } \mathrm{n}>5 \\
& \mathrm{CR} \leq 0.09 \text { for } \mathrm{n}=4 \\
& \mathrm{CR} \leq 0.05 \text { for } \mathrm{n}=3
\end{aligned}
$$

If computed $\mathrm{CR}$ is higher than the acceptable range, more information is supplied to the decision maker(s) or the expert(s) and the procedure is repeated till the value lies in the acceptable range.

Table 2: Random consistency index (RCI).

\begin{tabular}{|c|c|c|c|c|c|c|c|c|}
\hline $\mathrm{n}^{*}$ & 1 & 2 & 3 & 4 & 5 & 6 & 7 & 8 \\
\hline $\mathrm{RCI}$ & 0.00 & 0.00 & 0.58 & 0.90 & 1.12 & 1.24 & 1.32 & 1.41 \\
\hline $\mathrm{n}$ & 9 & 10 & 11 & 12 & 13 & 14 & 15 & \\
\hline $\mathrm{RCI}$ & 1.45 & 1.49 & 1.51 & 1.54 & 1.56 & 1.57 & 1.59 & \\
\hline
\end{tabular}

Remarks: ${ }^{*} \mathrm{n}$ is the number of criteria for comparison.

Step 4 Final conclusion: The AHP final process will serve as a tool to conclude the meaningful and objective numerical value of each criterion. The final step is the important task to determine the weighting factors indicating the relative importance or impact of each criterion. In the final step, the numerical weighting factors are calculated by using the average values of normalized weights of each criterion obtained from Step 3 of the process by all decision maker(s) or expert(s). It can be determined as follows:

$$
\mathrm{W}_{\mathrm{i}}=\frac{1}{\mathrm{~m}} \sum_{\mathrm{j}=1}^{\mathrm{m}} \mathrm{w}_{\mathrm{ij}} \text { for } \mathrm{i}=1,2, \ldots ., \mathrm{n}
$$

where $\mathrm{W}_{\mathrm{i}}=$ weighting factors of criteria $\mathrm{i}$,

wij $=$ normalized weight of criteria $\mathrm{i}$ by decision makers $\mathrm{j}$,

$\mathrm{m}=$ number of decision maker(s) or expert(s),

$\mathrm{n}=$ number of criteria for comparison.

\section{Study area}

Thailand covers an area of 513,115 sq.km. The country is bordered by Malaysia in the south, the Union of Myanmar in the west and northwest, the Loa People's Democratic Republic to the northeast, and Cambodia to the southeast. As reported in December 2012, the estimated population was about 64.6 million with a growth rate of 0.32 percent.

The country can be subdivided into five main geographical regions. They are namely the north, the central plains, the northeast, the east and the south. The northern region is mainly mountainous. It is the origin of four major rivers (Ping, Wang, Yom, and Nan) which converge to become the Chao Phraya River in the central plains. The northeast region occupies one-third of the country. The area is a high plateau at 100 to $200 \mathrm{~m}$ elevations. The eastern Thailand is bound by the 
Gulf of Thailand in the south and Cambodia in the east. The southern region of the country is located on the peninsula between the Andaman Sea of the Indian Ocean in the west and the South China Sea of the Pacific Ocean in the east.

The location of Thailand, the study area is shown in Figure 1. The average annual temperature varies in the range 23.3 to 28.4 degree Celsius. Average annual rainfall for the whole country is about $1,425 \mathrm{~mm}$. Total annual rainfall of all river basins is about 800,000 million $\mathrm{m}^{3}$ of which $75 \%$ of this is lost through evaporation and evapotranspiration. The remaining $25 \%\left(200,000\right.$ million $\left.\mathrm{m}^{3}\right)$ is stored in streams, rivers, and reservoirs.

According to the information from Department of Highway, as of September 2013 total length of the highway in the country is $51,610.888 \mathrm{~km}$. It consists of $15,720.566 \mathrm{~km}$ in northern region, $15,116.624 \mathrm{~km}$ in northeastern region, $10,881.481 \mathrm{~km}$ in central region and 9,892.217 km in southern region. Figure 2 shows the map of the highway network in Thailand.

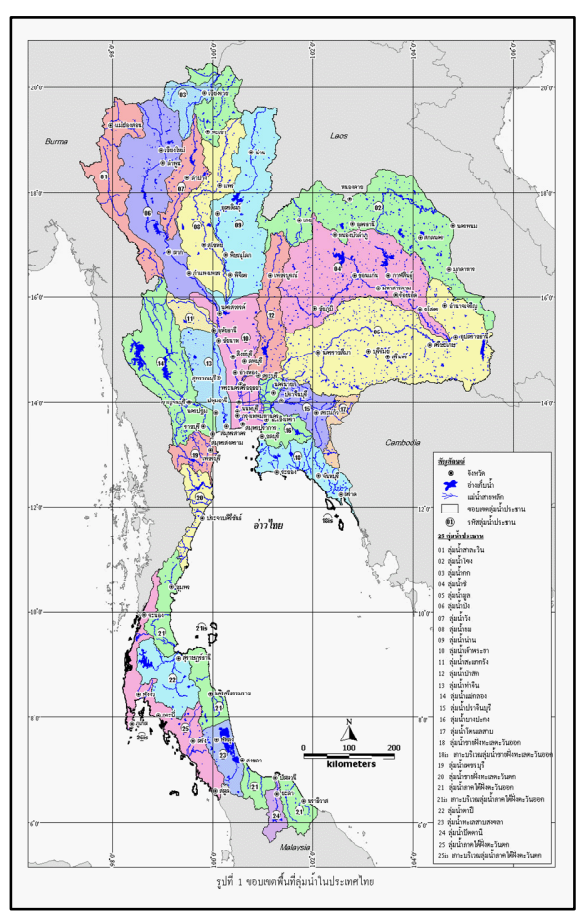

Figure 1: Location of study area (Source: [8]).

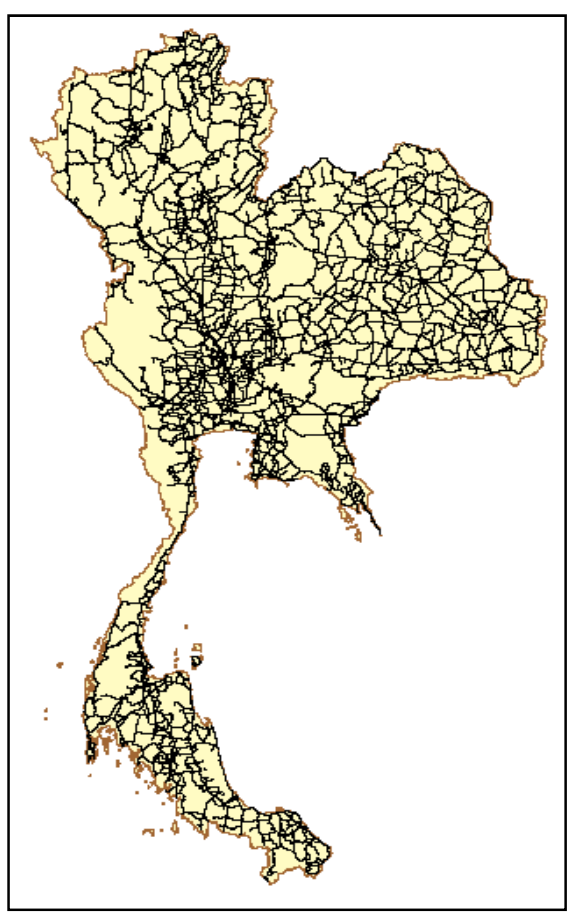

Figure 2: Highway network in Thailand (Source: The Department of Highways [5]). 


\section{Data collection}

Historic records of highway flood, hydrological time series and land topography were collected from the official database of Department of Highway (DOH), Thai Meteorological Department (TMD), Royal Irrigation Department (RID), Water Resources Department (WRD), Department of Public Works and Town and Country Planning (DPT) and Department of Disaster Prevention and Mitigation (DDPM). In correspondence with the task, the following information was collected:

1) Historic records of highway flood in the whole kingdom of Thailand during 1995-2012,

2) Daily and monthly climate and rainfall time series for the period of 61 years during 1952 to 2012 from 158 synoptic stations spatially distributed in the whole kingdom of Thailand,

Momentary peak discharge and gauge height from 229 synoptic stations spatially distributed within 25 major river basins in the whole kingdom of the country as shown the locations of all stations in Figure 3.

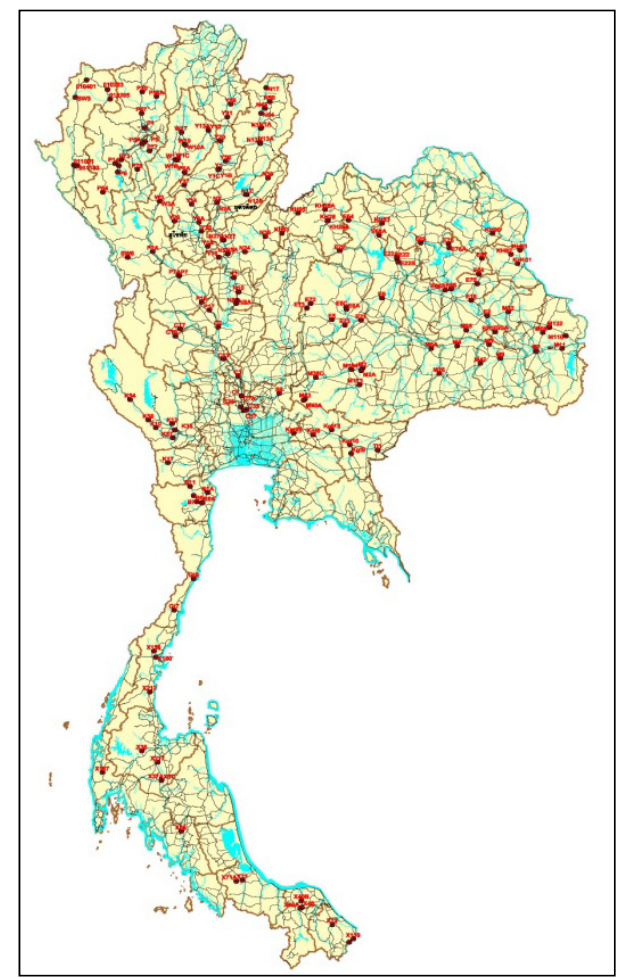

Figure 3: Location of hydro-meteorological station. 


\section{Results and discussions}

\subsection{Highway flood causes}

One of the objectives of this study is to investigate the causes of highway flood. Upon learning of the highway flood events within the country by taking into account the available resources and significance of the events, namely historical highway floods, hydrological time series, topography and stream conveyance capacities, it was found that highway flooding resulted from a combination of factors. The major causes are highway characteristics, hydrological characteristics and topographical characteristics. The highway characteristics play the important roles of flooding. It is simply due to the drains or the culverts are blocked or insufficient for large amounts of floodwater or flash storms. Drains can become blocked as a result of leaves or other debris covering the drain inlet, pipes blocked with debris, silt or tree roots and deteriorated or cracked pipe drains. It reflects this type of flood cause on highways on a frequent basis. Based on the data collected, it was found that out of 17 year historic records of highway flood in the whole kingdom of the country during 1995-2012, the maximum number of flood years in a highway is 14 .

The hydrological characteristics are another major highway flood cause. This is due to high river water levels preventing surface water draining from the highway, or the overbank flow due to the floodwater exceeds the conveyance capacities of the channels. In this research, the momentary peak discharge for the past 61 years during 1952-2012 from 229 synoptic stations spatially distributed within 25 major river basins in the whole kingdom of the country were used to compare with the conveyance capacity of the streams near to the highways. The stream conveyance capacity was evaluated using Manning Formula as follows:

$$
\mathrm{Q}=\frac{1}{\mathrm{n}} \mathrm{R}^{2 / 3} \mathrm{~S}^{1 / 2} \mathrm{~A}
$$

where

$\mathrm{Q}=$ Discharge $(\mathrm{cms})$,

$\mathrm{n}=$ Manning's coefficient which is defined based on the channel characteristics incorporated with previous studies by various agencies,

$\mathrm{A}=$ Cross sectional area $(\mathrm{m} 2)$,

$\mathrm{P}=$ Wetted perimeter $(\mathrm{m})$,

$\mathrm{S}=$ River bed slope.

$\mathrm{R}=$ Hydraulic radius $(\mathrm{m}),\left(\mathrm{R}=\frac{\text { ฤ }}{\mathrm{P}}\right)$

Overlaying the historical flooding of highways near to the streams with the channel conveyance capacities, it was found that overbank flooding occurred when flow events exceed the bank full capacity of the channel and therefore spill over into the highways. Hence, less stream conveyance capacity than the momentary peak discharge implies higher chance of overbank flood. 
According to the list of flood risk areas collected from the Department of Disaster Prevention and Mitigation (DDPM), the basin's topography is another significant factor contributing to the highway flooding. Highway on flood-prone areas for example on floodplain, low-lying or flat areas would naturally be affected by river overbank flooding and high tides or storms in coastal areas. In addition, the highways on steep landscapes are vulnerable to flash flood.

\subsection{Weighting factors of highway flood causes}

The results of MCA based on the AHP to determine the weighting factors of importance for each cause of the highway flood for the whole Kingdom of Thailand are presented in the following sections.

\subsubsection{Problem decomposition}

The first step of the AHP is to decompose the decision problem into a hierarchy of more easily comprehended sub-problems. In this study, the problem was explored as the criteria or causes/factors influencing the highway flood, namely highway characteristics, hydrological characteristics and land topography. The importance of the inundated area, depth and time of highway flooding is considered in this study to be equal. This is due to the reason that the flood at any depth and any time span cause jeopardize to human lives and losses. In order to avoid the potential risk to life, their importance is therefore considered to be equal. Schematic of AHP hierarchy for weighting factors determination of the highway flood causes is shown in Figure 4.

\subsubsection{Establish priorities}

Priorities among the elements of the hierarchy were established by making a series of judgments based on pair-wise comparisons of the elements. It implies how one impact plays the influence on the cause of highway flood in comparison with another one in the hierarchy. In this study, the priorities are absolute numbers between zero to nine. The scale ranges from 0 for 'least effect than', to 1 for 'equal', and to 9 for 'absolutely more important than' covering the entire spectrum of the comparison as shown in Table 3 .

To clearly present how to proceed the AHP, the weight given by one of our researchers to the criteria influencing the causes of highway flood is illustrated in Table 4. This researcher considered that the highway characteristics and the hydrological characteristics play equal effect to the highway flooding (level of importance is 1). But the highway characteristics play higher influence to the highway flooding than the topographical characteristics, but not much (level of importance is 2). And this researcher decided that the hydrological characteristics play slight higher influence to the highway flooding than the topographical characteristics (level of importance is 2). 


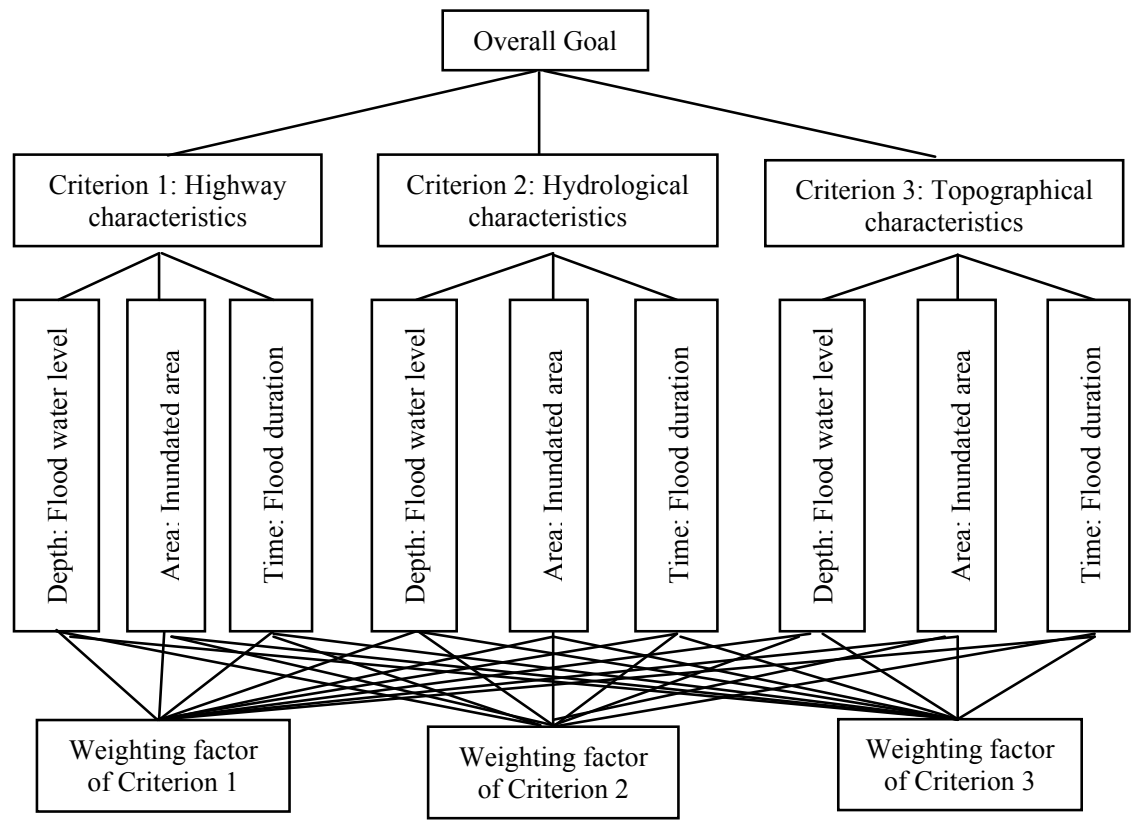

Figure 4: $\quad$ Schematic of AHP hierarchy to determine the weighting factors influencing the highway flood.

Table 3: Level of importance of each criterion.

\begin{tabular}{|c|c|l|}
\hline $\begin{array}{c}\text { Level of } \\
\text { importance }\end{array}$ & $\begin{array}{c}\text { Meaning of } \\
\text { Importance }\end{array}$ & \multicolumn{1}{c|}{ Description } \\
\hline 1 & Equal & Both criteria play equal influence to the cause of highway flood. \\
\hline 3 & Moderate & $\begin{array}{l}\text { One criterion plays moderate higher influence to the cause of } \\
\text { highway flood than another one }\end{array}$ \\
\hline 5 & $\begin{array}{c}\text { Very } \\
\text { important }\end{array}$ & $\begin{array}{l}\text { One criterion plays significant higher influence to the cause of } \\
\text { highway flood than another one }\end{array}$ \\
\hline 7 & $\begin{array}{c}\text { Very, very } \\
\text { important }\end{array}$ & $\begin{array}{l}\text { One criterion obviously plays significant higher influence to the } \\
\text { cause of highway flood than another one }\end{array}$ \\
\hline 9 & $\begin{array}{c}\text { Extreme } \\
\text { important }\end{array}$ & $\begin{array}{l}\text { One criterion plays extreme significant higher influence to the } \\
\text { cause of highway flood than another one }\end{array}$ \\
\hline $2,4,6,8$ & \multicolumn{2}{|c}{ In between } \\
\hline
\end{tabular}

Table 4: Illustrated matrix of priorities of the $1^{\text {st }}$ researcher.

\begin{tabular}{|l|c|c|c|}
\hline \multicolumn{1}{|c|}{ Criteria } & $\begin{array}{c}\text { Highway } \\
\text { characteristics }\end{array}$ & $\begin{array}{c}\text { Hydrological } \\
\text { characteristics }\end{array}$ & $\begin{array}{c}\text { Topography } \\
\text { characteristics }\end{array}$ \\
\hline Highway Characteristics & 1 & 1 & 2 \\
\hline Hydrological Characteristics & 1 & 1 & 2 \\
\hline Topography Characteristics & 0.5 & 0.5 & 1 \\
\hline
\end{tabular}




\subsubsection{Consistency check}

We check the consistency of the judgments by calculating the consistency index CI using eqn (1) as CI $=\frac{\lambda-3}{3-1}$. To determine $\lambda$ by using eqn (2), the normalized weights $\left(\mathrm{w}_{\mathrm{i}}\right)$ of each criterion were computed. For the highway and the hydrological characteristics (columns 1 and 2), the relative priorities (pair-wise comparison between criteria $i$ and $j$ are $\left[\begin{array}{l}1 \\ 1 \\ 0.5\end{array}\right]$, therefore the normalized weight $\left(\mathrm{w}_{\mathrm{i}}\right)$ is $\left\lfloor\begin{array}{l}0.4 \\ 0.4 \\ 0.2\end{array}\right\rfloor$. For the topographical characteristics, the relative priorities (column 3 ) are $\left[\begin{array}{l}2 \\ 2 \\ 1\end{array}\right]$, therefore the normalized weight $\left(\mathrm{w}_{\mathrm{i}}\right)$ is $\left[\begin{array}{l}0.4 \\ 0.4 \\ 0.2\end{array}\right\rfloor$. The average normalized weight is therefore equal to $\left[\begin{array}{l}0.4 \\ 0.4 \\ 0.2\end{array}\right\rfloor . \lambda$ can then be determined as follows:

$$
\begin{gathered}
\lambda=\{(1+1+0.5) \times 0.4\}+\{(1+1+0.5) \times 0.4\}+\{(2+2+1) \times 0.2\}=3 \\
\text { and } \mathrm{CI}=\frac{3-3}{3-1}=0 .
\end{gathered}
$$

As shown in Table 2, for $\mathrm{n}=3$, RCI is 0.58 . Consistency ratio (CR) can then be computed as $\mathrm{CR}=\frac{0}{0.58}=0$, which lies in the acceptable range (acceptable range is 0.05 for $n=3$ ). It implies that the weight given to the criteria influencing the causes of highway flood based on AHP of this researcher is consistent. It means that this researcher considered that the highway and the hydrological characteristics were equally weighted as $40 \%$ importance as the cause of highway flood. The land topography was weighted by this researcher to be $20 \%$ influence to the cause of highway flood.

In this study, another two researchers did a series of judgments based on the pair-wise comparisons of the elements by deciding all three criteria play equal effects to the highway flooding. Then, consistency of the judgments was checked as described in earlier sections. 


\subsubsection{Weight of criteria influencing highway flood causes}

In the final step, the numerical weighting factors given to the criteria influencing the causes of highway flooding were calculated by using the average values of normalized weights of each criterion obtained from all researchers as shown in Table 5. It was then concluded that based on the AHP results, the highway and the hydrological characteristics were equally weighted as 35\% importance as the cause of highway flood. And the land topography was weighted as $30 \%$ influence to the cause of highway flood.

Table 5: Results of weights given to the criteria influencing the highway flood.

\begin{tabular}{|l|c|c|c|c|}
\hline \multirow{2}{*}{ Criteria } & \multicolumn{3}{|c|}{ Researchers } & \multirow{2}{*}{ Average } \\
\cline { 2 - 4 } & $1^{\text {st }}$ & $2^{\text {nd }}$ & $3^{\text {rd }}$ & \\
\hline Highway characteristics & 0.4 & 0.33 & 0.33 & 0.35 \\
\hline Hydrological characteristics & 0.4 & 0.33 & 0.33 & 0.35 \\
\hline Topographical characteristics & 0.2 & 0.33 & 0.33 & 0.30 \\
\hline
\end{tabular}

\section{Conclusions}

Flood is one of the major natural disasters frequently affect millions of people in Thailand. To help reducing the highway flood hazard, and preparing the information for further use to determine the highway flood hazard level, the causes of highway flood and the weighting factors of criteria influencing the highway flood were investigated. Historic records of highway flood in the whole kingdom of Thailand during 1995-2012, historic records of 61 year time series during 1952 to 2012 from synoptic stations spatially distributed in the whole kingdom of the country and land topographical data were used in this part of study. It has been found that the major causes of highway flooding in Thailand are the highway characteristics, the hydrological characteristics and the land topographical characteristics. According to the results using the Multi Criteria Analysis (MCA) based on the Analytic Hierarchy Process (AHP), the highway and the hydrological characteristics were equally weighted as $35 \%$ importance as the cause of highway flood. And the land topography was weighted as $30 \%$ influence to the cause of highway flood. The weighting factors of criteria influencing the highway flood obtained in this study are applicable to set the priority for working out to fix the problems and help reducing the flood incidents. In addition, these factors are the essential information for further study to classify the degree of highway flood hazard for enable flood monitoring and flood warning in hazardous areas. This is recommended for further study on highway flood hazard mapping.

\section{References}

[1] Somchit, A., Fowze, J.S.M., Bormudoi, A., Khazaroka, A. \& Samarakoon, L., Flood hazard mapping in Nan River Basin. Proc. of the $7^{\text {th }}$ Annual 
Mekong Flood Forum Bangkok, Mekong River Commission Regional Flood Management and Mitigation Centre (RFMMC) Thailand: Bangkok, 2009.

[2] World Bank Group, Feasibility study of flood modelling in Upper Pasak River Basin, Petchaboon/Thailand, World Bank Group, 2011.

[3] Department of Disaster Prevention and Mitigation, Study on flood hazard map in developing countries, Pacific Consultants International, 2009.

[4] Department of Disaster Prevention and Mitigation, Early Warning system installation in flood and land slide risk areas for budget years 2008-2012, 2008.

[5] Budhakooncharoen, S., Working paper for highway flood hazard mapping, for Department of Highways, 2012.

[6] Saaty, T.L., A Scaling Method for Priorities in Hierarchical Structures. Journal of Mathematical Psychology, 1970.

[7] Saaty, T.L., The Analytic Hierarchy Process, McGraw Hill, New York, USA, 1980.

[8] 25 Major river basins of Thailand. http://water.rid.go.th/hyd/basin/ 25basin.htm. 